\title{
Sickle red cells as danger signals on proinflammatory gene expression, leukotriene B4 and interleukin-1 beta production in peripheral blood mononuclear cell
}

\author{
Thassila N. Pitanga ${ }^{a, b}$, Ricardo R. Oliveira ${ }^{a}$, Dalila L. Zanette ${ }^{a}$, Caroline C. Guarda ${ }^{a}$, Rayra P. Santiago ${ }^{\text {a }}$, \\ Sanzio S. Santana ${ }^{a}$, Valma M.L. Nascimento ${ }^{c}$, Jonilson B. Lima ${ }^{a}$, Graziele Q. Carvalho ${ }^{a}$, Vitor V. Maffili ${ }^{a}$, \\ Magda O.S. Carvalho a,d, Luiz C.J. Alcântara ${ }^{a}$, Valéria M. Borges ${ }^{a}$, Marilda S. Goncalves ${ }^{\mathrm{a}, e, *}$ \\ a Fundação Oswaldo Cruz, Centro de Pesquisas Gonçalo Moniz - FIOCRUZ/BA, 40296710 Salvador, Bahia, Brazil \\ ' Instituto de Ciências da Saúde (ICS), Universidade Federal da Bahia (UFBA), 40110902 Salvador, Bahia, Brazil \\ ${ }^{\mathrm{c}}$ Fundação de Hematologia e Hemoterapia da Bahia (HEMOBA), 40286240 Salvador, Bahia, Brazil \\ ${ }^{\mathrm{d}}$ Hospital Universitário Professor Edgard Santos (HUPES), UFBA, 40110060 Salvador, Bahia, Brazil \\ e Faculdade de Farmácia, UFBA, 40170115 Salvador, Bahia, Brazil
}

\section{A R T I C L E I N F O}

\section{Article history:}

Received 23 December 2015

Received in revised form 8 March 2016

Accepted 21 March 2016

\section{Keywords:}

Sickle cell anemia

Sickle red cell

IL-1 $\beta$

Leukotriene B4

NLRP3 inflammasome

Toll-like receptors

\begin{abstract}
A B S T R A C T
This study tested the hypothesis that sickle red blood cell (SS-RBC) induce Toll-like receptors (TLR) and Nod-like receptor family, pyrin domain containing 3 (NLRP3)- inflammasome expression in peripheral blood mononuclear cells (PBMC). TLR and NLRP3 inflammasome could contribute to the maintenance of the inflammatory status in sickle cell anemia (SCA) patients, since SS-RBC act as danger signals activating these pathways. In this study, first, we evaluated $\operatorname{TLR}(2,4,5$ and 9), NLRP3, Caspase-1, interleukin (IL)$1 \beta$ and $I L-18$ expression in PBMC freshly isolated from SCA patients (SS-PBMC) in comparison with PBMC from healthy individuals (AA-PBMC). In the second moment, we investigated whether SS-RBC could interfere with the expression of these molecules in PBMC from healthy donor, in the absence or presence of hydroxyurea (HU) in vitro. TLRs and NLRP3 inflammasome expression were investigated by qPCR. IL$1 \beta$, Leukotriene-B4 $\left(\mathrm{LTB}_{4}\right)$ and nitrite production were measured in PBMC (from healthy donor) culture supernatants. TLR2, TLR4, TLR5, NLRP3 and IL-1 $\beta$ were highly expressed in SS-PBMC when compared to AA-PBMC. Additionally, SS-RBC induced TLR9, NLRP3, Caspase-1, IL-1 $\beta$ and $I L-18$ expression and induced IL-1 $\beta, \mathrm{LTB}_{4}$ and nitrite production in PBMC cultures. HU did not prevent TLR and NLRP3 inflammasome expression, but increased TLR2 and IL-18 expression and reduced nitrite production. In conclusion, our data suggest that TLR and inflammasome complexes may be key inducers of inflammation in SCA patients, probably through SS-RBC; also, HU does not prevent NLRP3 inflammasome- and TLR-dependent inflammation, indicating the need to develop new therapeutic strategies to SCA patients that act with different mechanisms of those observed for HU.
\end{abstract}

(c) 2016 Elsevier Ltd. All rights reserved.
Abbreviations: AA-PBMC, peripheral blood mononuclear cells freshly isolated from healthy individuals; AA-RBC, red blood cell from healthy individuals; ASC, apoptosis-associated speck-Like protein containing card; DAMPs, damageassociated molecular pattern molecules (DAMPs); HbF, fetal hemoglobin; HMGB1, high-mobility group protein B1; HU, hydroxyurea; LT, leukotriene; LTB4, leukotriene B4; NLR, Nod-like receptors; NLRP3, Nod-like receptor family, pyrin domain containing 3; PAMP, pathogen-associated molecular pattern; PBMC, peripheral blood mononuclear cells; RBC, red blood cell; SCA, sickle cell anemia; SCD, sickle cell disease; SS-PBMC, peripheral blood mononuclear cells freshly isolated from sickle cell anemia patients; SS-RBC, red blood cells from sickle cell anemia patients; TLR, Toll-like receptors.

* Corresponding author at: Centro de Pesquisas Gonçalo Moniz, Laboratório de Hematologia, Genética e Biologia Computacional, Rua Waldemar Falcão, n. 121, Candeal, 40296710 Salvador, Bahia, Brazil.

E-mail address: mari@bahia.fiocruz.br (M.S. Goncalves).

\section{Introduction}

Sickle cell anemia (SCA) is a genetic disorder characterized by the production of abnormal red blood cells, homozygosity of hemoglobin $\mathrm{S}(\mathrm{HbS})$ and oxygen transport dysfunction. Clinically, SCA patients can be in a steady state, with subclinical manifestations, or in crisis, showing systemic inflammation, with vasoocclusive phenomena and painful episodes, as well as susceptibility to infections and hemolysis [1-3]. SCA has been characterized as a chronic inflammatory state, with abnormal activation and elevated number of peripheral blood mononuclear cells (PBMCs), 
endothelial dysfunction and an increased level of multiple inflammatory mediators [4-7].

Endothelial cells, leukocytes and platelets are constantly exposed to reticulocytes, normal and sickle red blood cells. This exposure contributes to the systemic inflammation and prothrombotic phenomena $[8,9]$. Nitric oxide (NO) is an important molecule involved in the maintenance of vascular homeostasis. Moreover, sickle red blood cells (SS-RBC) induces leukotriene (LT) production, an inflammatory mediator derived from arachidonic acid metabolism, which induces leucocytes migration and activation [10-13]. In addition to increased levels of NO metabolites (nitrite and nitrate), SCA patients have increased levels of $\mathrm{LTB}_{4}$, even in steady state, which are associated with the severity of clinical outcome, particularly during vaso-occlusion episodes [14-16].

Since the presence of SS-RBC is a typical feature in SCA patients, more investigation is necessary in order to identify its role in the amplification and maintenance of inflammatory immune response within these conditions. Innate immune system is able to recognize danger-associated molecular patterns (DAMPs) by TLRs (Toll-like receptors) and Nod-like receptors (NLR) [7,17]. Since TLRs and NLRs are a family of evolutionary conserved proteins that recognize pathogen (PAMPs) and DAMPs associated molecular patterns, it is expected that these receptors play a critical role in SCA pathogenesis [17-21].

In humans, at least ten TLRs (TLR1 to TLR10) are reported, each of which has specificity for a particular PAMP or DAMP [22]. Several studies have shown association between expression of these receptors and inflammatory conditions [23-25]. In SCA, for instance, high-mobility group protein B1 (HMGB1) and heme are DAMPs that act as TLR4 agonists [18,19,21,26-28]. Other TLR, such as TLR2, TLR5 and TLR9, were recently shown to recognize cellular residues and other endogenous molecules, acting as signals for tissue injury $[25,29,30]$.

Nod-like receptors, in turn, oligomerizes under activation resulting in an inflammatory multi-protein platform, known as inflammasome. HMGB1, iron and heme are the major DAMPs considered as NLR agonists [19,21,31-34]. Classically, inflammasome consists of NLRP (usually NLRP3, Nod-like receptor family, pyrin domain containing 3 ), inflammatory protease caspase- 1 and the apoptosis-associated speck-Like protein containing card (ASC). Then, active caspase- 1 converts the inflammatory cytokines IL-1 $\beta$ and IL-18 into active forms [35-41]. High levels of these cytokines have been associated with different clinical inflammatory conditions, such as multiple sclerosis, cancer, Alzheimer's disease, Behcet's disease, arthritis and SCA [7,17,42-48].

Thus, TLRs and NLRP3 inflammasome may play a role in the immunopathogenesis of inflammatory diseases, such as SCA, contributing to its severity. However, these pathways can be responsible for therapeutic failure in regard of inflammation. Hydroxyurea (HU) is the drug approved for treatment of SCA patients, and is a cytotoxic agent that inhibits ribonucleotide reductase enzyme and leads to improvement in levels of fetal hemoglobin (HbF), hydration of RBC and reduction of SS-RBC-endothelial interaction $[49,50]$. Such effects are associated with improvement of clinical status of the patient and reduction of inflammatory markers $[49,51]$. However, it is not known whether HU interferes with TLR or NLR signaling pathways.

The role that inflammatory receptors, such as TLRs and NLRs, play in the immunopathogenesis of SCA, as well as the contribution of $\mathrm{RBC}$ from SCA patients to the induction of inflammation and the role of $\mathrm{HU}$ in this scenario are still not clear. In this study, we evaluated the gene expression of TLR (TLR2, TLR4, TLR5, TLR9) and NLRP3-inflammasome components (NLRP3, caspase-1, IL-1 $\beta$ and IL-18) in PBMC of SCA patients. Moreover, we investigated the effect of SS-RBC on the expression of these genes and production of IL-1 $\beta$ cytokine, $\mathrm{LTB}_{4}$ and nitrite in PBMC from healthy controls, as well as in vitro effect of HU in these conditions.

\section{Materials and methods}

\subsection{Study subjects}

A cross sectional study was performed to include 12 SCA patients (age $9.1 \pm 4.7$ years), recruited at the Fundação de Hematologia e Hemoterapia do Estado da Bahia (HEMOBA). All patients were in steady state, characterized by absence of blood transfusion in a period of four months prior to blood draw. In addition, patients included in this study did not show any infection, hospitalization or vaso-occlusive event, and were not under antibiotics, corticosteroids or HU treatments, but all patients were under treatment with folic acid. The control group consisted of 9 healthy individuals (age $12.4 \pm 5.6$ years) recruited at the Pharmacy College (FacFAR) of Universidade Federal da Bahia (UFBA). This group was characterized by absence of hematological disorders or inflammatory conditions. All procedures followed were in accordance and approved by the Research Ethics Committee of the Fundação Oswaldo Cruz FIOCRUZ, Brazil; and also with the Helsinki Declaration of 1975 , and its revisions. Informed consent was obtained from all patients (or their parents/legal guardians).

\subsection{Blood samples and preparation of red blood cells}

Venous blood was collected from patients and controls using EDTA to determine hemoglobin profile and to obtain red blood cells (RBC). Briefly, each blood sample was centrifuged at $270 \mathrm{~g}$ for $10 \mathrm{~min}$ to discard the platelet-rich plasma (PRP). Leukocytes and PRP were removed by aspiration, and RBC were washed 3 times at $170 \mathrm{~g}$ for $5 \mathrm{~min}$ with sterile phosphate buffered saline (PBS) ( $\mathrm{pH} 7.3$ ). RBC concentrate were assessed for leukocyte and platelet contamination by staining with trypan blue and then analyzed by using a phase contrast microscope (Olympus CK2, Center Valley, PA, USA).

\subsection{Hematological and biochemical analysis}

Hematological and biochemical parameters from patients and controls included in this studied was obtained. RBC, platelets, leukocyte, reticulocyte, hemoglobin, fetal hemoglobin, hematocrit, ferritin and C-reactive protein of the SCA patients and controls are shown in Table 1 . The mean age of patients and healthy individuals was similar.

Table 1

Hematological and biochemical parameters of steady-state SCA patients and healthy volunteers.

\begin{tabular}{lrrr}
\hline & $\begin{array}{l}\text { SCA patients } \\
(\mathrm{n}=12) \\
(\text { mean } \pm \mathrm{SD})\end{array}$ & $\begin{array}{l}\text { Healthy } \\
\text { individuals } \\
(\mathrm{n}=9) \\
(\text { mean } \pm \mathrm{SD})\end{array}$ & $p$ value $^{*}$ \\
& & $12.44 \pm 5.60$ & \\
\hline Age $($ years $)$ & $2.08 \pm 4.72$ & $4.78 \pm 0.41$ & $<0.1864$ \\
RBC $\left(\times 10^{6} / \mathrm{mL}\right)$ & $441.00 \pm 118.10$ & $307.10 \pm 49.85$ & 0.0001 \\
Platelets $\left(\times 10^{9} / \mathrm{mL}\right)$ & $6767 \pm 1716$ & 0.0002 \\
Leukocyte $\left(\times 10^{9} / \mathrm{mL}\right)$ & $15,178 \pm 4474$ & $0.76 \pm 0.17$ & 0.0004 \\
Reticulocyte $(\%)$ & $7.25 \pm 2.05$ & $13.23 \pm 1.27$ & 0.0004 \\
Hemoglobin $(\mathrm{g} / \mathrm{dL})$ & $8.68 \pm 1.03$ & $0.48 \pm 0.42$ & 0.0007 \\
Fetal Hemoglobin $(\%)$ & $7.73 \pm 6.26$ & $39.43 \pm 3.18$ & 0.0004 \\
Hematocrit $(\%)$ & $25.34 \pm 3.53$ & $36.63 \pm 18.53$ & 0.0016 \\
Ferritin $(\mathrm{ng} / \mathrm{mL})$ & $246.30 \pm 213.80$ & $1.58 \pm 1.16$ & 0.0163 \\
C-reactive protein & $5.17 \pm 0.67$ & &
\end{tabular}

$S C A$ sickle cell anemia, $S D$ standard deviation, $R B C$ red blood cells.

* Mann-Whitney test; values to $p<0.05$ were considered a significant difference. 
Hematologic values and RBC indices were determined by using the electronic counter ABX Pentra and morphological analysis of red blood cells was performed by microscopic examination of blood smears stained with Wright. The hemoglobin profile was confirmed by HPLC in automated equipment (Variant I Bio-Rad). Reticulocytes were counted after supravital staining. Biochemical analyzes were determined by automated method and included the C-reactive protein. These analyses were performed using A25 equipment (AS Biosystems, Barcelona, Spain) at the Pharmacy College, UFBA.

\subsection{Peripheral blood mononuclear cells separation}

Fresh PBMC were obtained from peripheral blood of SCA patients $(n=12)$ and healthy individuals $(n=9)$ and by gradient centrifugation on Ficoll-Hypaque (GE Healthcare Bio-Sciences Corp. Piscataway, NJ, USA) at room temperature. Briefly, $10 \mathrm{~mL}$ of whole blood diluted with $10 \mathrm{~mL}$ PBS was carefully added in $15 \mathrm{~mL}$ of ficoll followed by centrifugation at $500 \mathrm{~g}$ for $30 \mathrm{~min}$. Mononuclear leukocyte layer was separated with PBS by centrifugation at $500 \mathrm{~g}$ for $10 \mathrm{~min}$. The pellet was washed two times with PBS and centrifuged at $180 \mathrm{~g}$ for $10 \mathrm{~min}$ to partially remove the platelets. Pellet was resuspended in RPMI-1640 medium (Gibco, Grand Island, NY, USA) supplemented with 10\% FBS (SigmaAldrich, St. Louis, MO, USA) and with $100 \mathrm{U} / \mathrm{ml}$ penicillin and $100 \mu \mathrm{g} / \mathrm{ml}$ streptomycin (Gibco, Grand Island, NY, USA).

Additionally, PBMC were isolated from one healthy donor, using the same procedures described above. These PBMC were used only for cell cultures challenged with $\mathrm{RBC}$ and were adjusted to $3 \times 10^{6}$ cells $/ \mathrm{mL}$ in $500 \mu \mathrm{L}$ of RPMI and distributed in 24 -well plate (Corning, Costar, Sigma-Aldrich, St. Louis, MO, USA).

\subsection{IL-1 $\beta$, leukotriene-B4 and nitrite production by PBMC cultures}

Experiments were independently set in the following manner: PBMC from the same healthy donor were cultured with 3\% RBC from 12 SCA patients (SS-RBC) and 9 healthy controls (AA-RBC) at $37{ }^{\circ} \mathrm{C}$ and $5 \% \mathrm{CO}_{2}$, in the presence or absence of $100 \mu \mathrm{M} \mathrm{HU}$ (Sigma-Aldrich, Saint Louis, MO, USA) [50,52]. After 24 h, supernatants were collected and used for the detection of IL-1 $\beta$ (R\&D Systems, Minneapolis, USA) and $\mathrm{LTB}_{4}$ (Cayman Chemical Company, Ann Arbor, MI, USA) using ELISA kits, according to the manufacturer's instructions. Nitrite production was assessed in the same culture supernatants by determining nitrite accumulation, using the Griess method [53]. Similar methods were performed to measure these inflammatory mediators in sera of SCA patients and healthy volunteers (Table 2).

\subsection{Expression of mRNA for Toll-like receptors and NLRP3- inflammasome components}

Total RNA was isolated from PBMC freshly isolated from SCA patients and healthy controls as well as PBMC from healthy donor challenged with AA or SS-RBC using Trizol Reagent (Invitrogen, Life Technologies, Carlsbad, CA, USA) according to the manufacturer's

Table 2

Steady-state inflammatory markers values of the SCA patients and healthy individuals.

\begin{tabular}{lccc}
\hline & $\begin{array}{l}\text { SCA patients } \\
(\mathrm{n}=12)(\text { mean } \pm \mathrm{SD})\end{array}$ & $\begin{array}{l}\text { Healthy volunteers } \\
(\mathrm{n}=9)(\text { mean } \pm \mathrm{SD})\end{array}$ & $p$ value $^{*}$ \\
\hline $\mathrm{IL}-1 \beta(\mathrm{pg} / \mathrm{mL})$ & $9.12 \pm 4.01$ & $2.18 \pm 0.49$ & 0.018 \\
$\mathrm{LTB}_{4}(\mathrm{pg} / \mathrm{mL})$ & $992.40 \pm 771.20$ & $285.80 \pm 110.10$ & 0.003 \\
Nitrite $(\mu \mathrm{M})$ & $35.61 \pm 15.73$ & $6.38 \pm 1.87$ & $<0.0001$ \\
\hline
\end{tabular}

Mann-Whitney test, values to $p<0.05$ were considered a significant difference. instructions and RNA concentrations were measured by NanoDrop $^{\mathrm{TM}}$ Lite Spectrophotometer (Thermo Fisher Scientific, Wilmington, MA, USA). Reverse transcription was performed with $400 \mathrm{ng}$ of total RNA using the High Capacity cDNA Reverse Transcription Kit (Applied Biosystems TM, Foster City, CA, USA) according to the manufacturer's instructions. The conditions used were $25^{\circ} \mathrm{C}$ for $10 \mathrm{~min}, 37^{\circ} \mathrm{C}$ for $120 \mathrm{~min}$ and $85^{\circ} \mathrm{C}$ for $5 \mathrm{~min}$.

Gene expression analysis was evaluated by quantitative realtime PCR (qPCR) on an ABI 7500 FAST Real-Time PCR equipment (Applied Biosystems TM, Foster City, CA, USA) for TLR2, TLR4, TLR5, TLR9, NLRP3, IL-1 $\beta$ and IL-18, Caspase-1, GAPDH and $\beta$-ACTIN genes with Power SYBR ${ }^{\circledR}$ Green, according to the manufacturer's instructions. The standard qPCR conditions were as follows: $10 \mathrm{~min}$ at $95^{\circ} \mathrm{C}$, followed by 40 cycles at $95^{\circ} \mathrm{C}$ for $15 \mathrm{~s}$, and $60^{\circ} \mathrm{C}$ for $60 \mathrm{~s}$. Primers used for qPCR reactions are shown in Table 3. After amplification and dissociation curve runs, the values of threshold cycle $(\mathrm{Ct})$ were obtained by using the Operational Program $7500^{\mathrm{TM}}$ System (Applied Biosystems, TM, Foster City, CA, USA). The intra-assay precision was calculated using the equation $\mathrm{E}=(-1 /$ slope $)$ to confirm precision and reproducibility of qPCR. The expression levels were normalized based on the geometric mean of GAPDH and $\beta$-ACTIN (endogenous controls). Relative expression folds were calculated based on $2^{-\mathrm{ddCt}}$ method [54] using non-stimulated PBMC as calibrator.

\subsection{Statistical analysis}

Average values of quantitative variables were compared between groups using the Mann-Whitney test for non-normally distributed data. qPCR was performed in triplicate and values were expressed as mean \pm SEM. Values of $p<0.05$ were considered a significant difference. All data were analyzed using Prism 5.1 software (GraphPad, San Diego, CA, USA).

\section{Results}

\subsection{Levels of inflammatory mediators were higher in sera of SCA patients compared to healthy volunteers}

Serum and whole blood samples from SCA patients $(\mathrm{n}=12)$ and healthy individuals $(n=9)$ were evaluated in this study and hematological and biochemical parameters are summarized in Table 1.

Table 3

Primer sequences used for qPCR.

\begin{tabular}{ll}
\hline Gene & Primer $\left(5^{\prime} \rightarrow 3^{\prime}\right)$ \\
\hline$T L R-2$ & F: TTG TGA CCG CAA TGG TAT CTG \\
& R: GCC CTG AGG GAA TGG AGT TT \\
$T L R-4$ & F: GGC CAT TGC TGC CAA CAT \\
& R: CAA CAA TCA CCT TTC GGC TTT T \\
$T L R-5$ & F: TGT ATG CAC TGT CAC TCT GAC TCT GT \\
& R: AGC CCC GGA ACT TTG TGA CT \\
$T L R-9$ & F: AAC CTC CCC AAG AGC CTA CAG \\
& R: CAG CAC TTA AAG AAG GCC AGG TA \\
$N L R P 3$ & F: TGC CCC GAC CCA AAC C \\
& R: GAA GCC GTC CAT GAG GAA GA \\
CASPASE-1 & F: AAA AAA TCT CAC TGC TTC GGA CAT \\
& R: TCT GGG CGG TGT GCA AA \\
$I L-1 \beta$ & F: AGC TAC GAA TCT CCG ACC AC \\
IL-18 & R: CGT TAT CCC ATG TGT CGA AGA A \\
& F: ATC GCT TCC TCT CGC AAC A \\
GAPDH & R: TCT ACT GGT TCA GCA GCC ATC TT \\
& F: CAC ATG GCC TCC AAG GAG TAA \\
& R: TGA GGG TCT CTC TCT TCC TCT TGT \\
& F: CCT GGC ACC CAG CAC AAT \\
& R: GCC GAT CCA CAC GGA GTA CT
\end{tabular}

TLR Toll like receptor, NLR NOD like receptor, $F$ Forward sequence, $R$ Reverse sequence. 
As expected, all hematological and biochemical results were different between patients and healthy individuals. Regarding inflammatory mediators, serum levels of IL-1 $\beta(9.12 \pm 4.01)$, LTB4 $(1091.00 \pm 688.30)$ and nitrite $(35.61 \pm 15.73)$ in SCA patients were higher when compared to healthy volunteers $(2.18 \pm 0.49$, $p=0.018 ; \quad 285.80 \pm 110.10, \quad p=0.003 ; \quad 6.38 \pm 1.87, \quad p<0.0001$, respectively, Table 2 ).

\subsection{TLR and NLRP3 inflammasome components are highly expressed in PBMC of SCA patients}

SCA is an inflammatory condition in which the innate immune response may play an important role, both in initiating and maintaining the pathological response. For this reason, we hypothesized that SS-RBC act as danger signals that induce gene expression of $T L R$ and NLRP3 inflammasome components. We first examined whether the expression of TLR2, TLR4, TLR5, TLR9, NLRP3, caspase-1, IL-1 $\beta$ and $I L-18$, assessed by $\mathrm{qPCR}$, differed between PBMC obtained from SCA patients (SS-PBMC, $\mathrm{n}=12$ ) and healthy individuals (AA-PBMC, $\mathrm{n}=9$ ).

As shown in Fig. 1a-c, expression of TLR2, TLR4 and TLR5 was significantly higher in SS-PBMC $(0.46 \pm 0.17 ; 47.50 \pm 21.46$ and $0.88 \pm 0.23)$ when compared to AA-PBMC (0.20 \pm 0.07 ; $20.60 \pm 1.75$ and $0.37 \pm 0.09$ respectively, $\mathrm{p}<0.05)$. On the other hand, TLR9 was equally expressed in both SS-PBMC and AA-PBMC (Fig. 1d).

Expression of NLRP3 and IL-1 $\beta$ was significantly higher in SS-PBMC ( $2.30 \pm 1.02$ and $2.84 \pm 1.08)$ as compared to AA-PBMC $(0.75 \pm 0.13$ and $1.24 \pm 0.38$ respectively, $p<0.05)$ (Fig. 1 e and $g$ ). On the other hand, mRNA expression of Caspase- 1 and $I L-18$ did not differ between PBMC from healthy individuals and SCA patients (Fig. 1f and h).

\subsection{SS-RBC induces TLR9 and NLRP3 inflammasome components expression in $P B M C$}

Assuming that TLRs are highly expressed in PBMC of SCA patients, we next tested whether SS-RBC are able to induce expression of TLR2, TLR4, TLR5 and TLR9 in PBMC culture. For this purpose, we isolated PBMC from the same healthy donor and incubated these cells in the presence of SS-RBC $(n=12)$ or AA-RBC $(n=9)$.

As shown in Fig. 2a-c, AA-RBC or SS-RBC were not able to induce expression of TLR2, TLR4 or TLR5, when compared to the basal expression of these receptors observed in unstimulated PBMC cultures. Nevertheless, it was noteworthy that SS-RBC, but not AA-RBC, were able to increase TLR9 expression, by almost 4-fold, when compared to unstimulated PBMC culture ( $p<0.05$; Fig. $2 \mathrm{~d}$ ). Therefore, SS-RBC were good inducers of TLR9 expression, an effect that was not observed with AA-RBC. This peculiarity is probably mediated by a danger signal that is present in the cell surface or actively released in the medium by SS-RBC and not by AA-RBC.

Since it has been shown that PBMC express mediators associated with NLRP3 inflammasome, we decided to investigate whether SS-RBC could act as a DAMP (eDAMP) driving expression of NLRP3 inflammasome-related molecules in PBMC culture. As shown in Fig. 2e-h, SS-RBC induced the expression of NLRP3, caspase-1, IL-1 $\beta$ and $I L-18$ in PBMC cultures, whereas AA-RBC were not able to induce these pattern of gene expression.

\subsection{Hydroxyurea treatment increases TLR2 and IL-18 expression}

$\mathrm{HU}$ is an antineoplastic drug used to treat SCA patients, of which the main beneficial effect expected is the improvement in $\mathrm{HbF}$ levels. However, it is not clear if HU directly interferes in the inflammatory condition of these patients. In order to address this issue, PBMC cultures were challenged with SS-RBC and treated or not with HU. These PBMC incubated with SS-RBC and treated with HU showed higher TLR2 gene expression $(1.03 \pm 0.20)$ when compared to untreated PBMC $(0.78 \pm 0.33 ; p<0.05$; Fig. $3 a)$. On the other hand, expression of TLR4, TLR5 and TLR9 were not affected by HU treatment (Fig. 3b-d).

As shown in Fig. 3e-g, expression of NLRP3, caspase- 1 and $I L-1 \beta$ were not significantly affected by $\mathrm{HU}$ treatment. In contrast, HU increased $I L-18$ expression $(1.64 \pm 0.23)$ by almost 2 -fold, when compared to untreated PBMC culture $(0.75 \pm 0.07 ; p<0.05$; Fig. $3 \mathrm{~h}$ ). Thus, besides the positive effect of $\mathrm{HU}$ on $\mathrm{HbF}$ production, our data suggests that this drug could be able to increase TLR2 and IL-18 inflammatory pathways.

\subsection{SS-RBC induce the production of IL-1 $\beta$ and LTB4, regardless of} hydroxyurea treatment, whilst this drug reduces nitrite production

In addition to assessing gene expression, we also evaluated IL$1 \beta$ secretion in PBMC culture upon activation of Nod-like receptors. We observed that SS-RBC induced higher production of IL-1 $\beta$ than AA-RBC (Fig. 4a). These data suggest that SS-RBC, as opposed to AA-RBC, can act as a DAMP, activating an inflammatory response mediated by receptors from the innate immune system.

HU treatment showed no effect in down-regulating IL-1 $\beta$ production induced by SS-RBC on PBMC culture (Fig. 4b). These findings suggest that this treatment does not modulate the IL-1 $\beta$ dependent inflammatory response.

It has been demonstrated that SCA patients have increased concentrations of $\mathrm{LTB}_{4}$ and NO metabolites $[13,15]$. Since $\mathrm{LTB}_{4}$ is a lipid involved in inflammation, we tested whether AA- or SS-RBC were able to induce its production in PBMC culture, and whether HU could regulate this scenario. We showed that SS-RBC induced higher production of $\mathrm{LTB}_{4}(6.92 \pm 2.19)$ when compared to AA$\operatorname{RBC}(3.19 \pm 0.27 ; p<0.05)$ (Fig. $4 c$ ), and this effect was not reversed by $\mathrm{HU}$ addition (Fig. $4 \mathrm{~d}$ ).

We also evaluated the concentration of nitrite, a NO metabolism product, in the supernatant of PBMC cultures challenged with RBC. As shown in Fig. 4e, SS-RBC $(73.34 \pm 26.12)$ induced significantly higher production of nitrite compared to AA-RBC (46.69 \pm 30.45 , $p<0.0001$ ). Moreover, it was noteworthy that HU treatment was able to reduce nitrite production when PBMC cultures were stimulated with SS-RBC ( $73.34 \pm 26.12)$, as compared to cultures stimulated with SS-RBC without HU $(46.69 \pm 30.45, p<0.05)$ (Fig. 4 f).

\section{Discussion}

The innate immune system acts as a first line of defense against pathogens, by recognizing PAMPs, but also senses DAMPs from sterile tissue injury. Upon its activation by innate receptors such as Toll and NOD like receptors (TLRs and NLRs respectively), the inflammatory response is initiated and sustained, for as long as the triggering agent is present. The inflammation in SCA is proposed to be dependent on TLR and NLR signaling since erythrocyte could be recognized as DAMPs $[7,19,34,55,56]$.

SS-RBC are known to activate and induce adhesion of mononuclear leukocytes (lymphocytes and monocytes) to vascular endothelium [5]. This knowledge led us to investigate the in vitro effect of RBC on the expression of TLR and NLRP3 inflammasome pathways in PBMC.

In this study we demonstrated that TLRs and NLRP3 inflammasome molecules are highly expressed in SS-PBMC, which showed higher expression of TLR2, TLR4, TLR5, NLRP3 and IL-1 $\beta$ genes when compared to AA-PBMC. TLR2 is important for the response against Gram-positive bacteria as well as against sterile inflammation by identifying different DAMPs. This receptor can form heterodimers with TLR4, which is able to recognize hemoglobin [57-59]. 

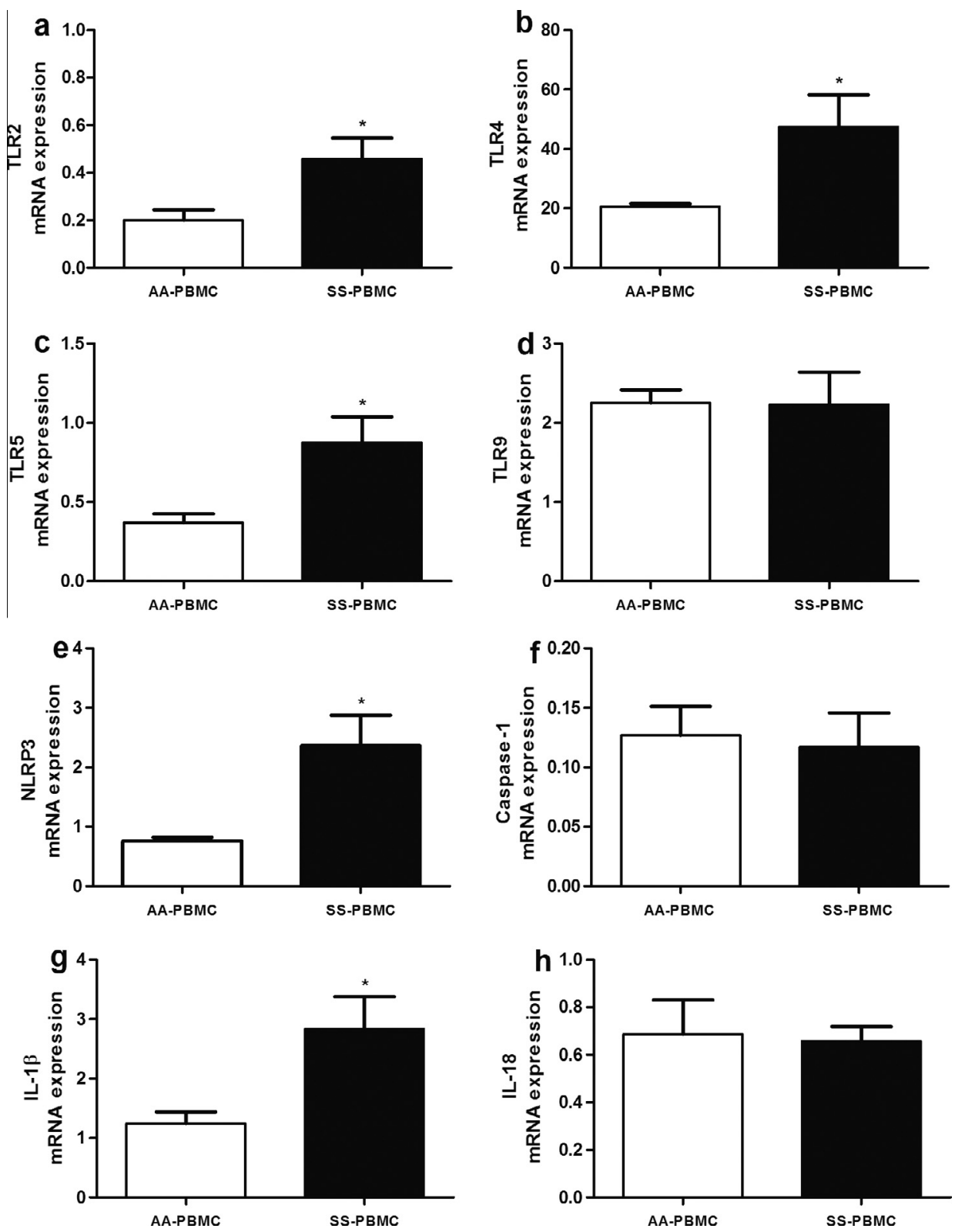

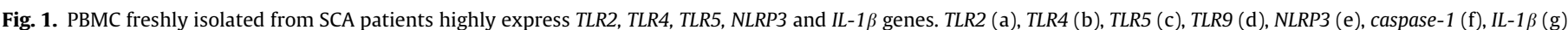

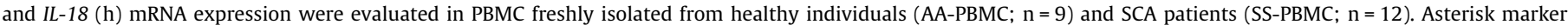

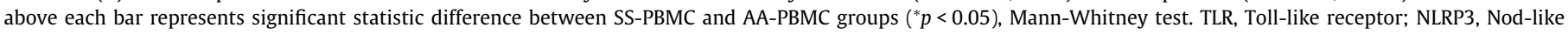
receptor family, pyrin domain containing 3; IL, interleukin; PBMC, peripheral blood mononuclear cells; SCA, sickle cell anemia.

Although LPS is a well described PAMP for TRL4, there are other agonists even in sterile conditions, such as HMGB1, HSP and heme $[18,19,60]$. Similarly, despite the importance of TLR5 in the defense against pathogens, there are evidences that this receptor is a severity biomarker for some inflammatory conditions [61-64]. Thus, the expression of these receptors in SS-PBMC could be due to continuous exposure to SS-RBC. Although we have only evaluated TLRs gene expression, and not TLR proteins, our findings suggest that SS-RBC can affect TLR and NLR pathways.

To test this hypothesis, we performed an experiment where PBMC cultures (from healthy donor) were challenged with RBC. In these experiments, SS-RBC induced higher TLR9 expression when compared to AA-RBC. Despite this, no differences in TLR9 expression was seen when we compared fresh SS-PBMC and AAPBMC. In the same experiments, TLR2, TLR4 and TLR5 gene expression levels were evaluated. In our results, TLR4 has been shown to be upregulated in freshly isolated SS-PBMC, reinforcing TLR4 importance to inflammation in SCA [18,19,33]. Despite this, we did not find any differences in gene expression of this receptor in PBMC culture challenged with SS-RBC in vitro. The same results were observed to TLR2 and TLR5 expression. These apparent discrepancies are likely due to the presence of additional factors regulating these TLR genes in the case of a complex, in vivo environment, which are not present in a controlled and restrict in vitro environment.

Our results show that TLR9 expression is increased in PBMC culture challenged by SS-RBC, but we did not find differences in its expression between fresh SS-PBMC and fresh AA-PBMC. To our knowledge, there is not description of TLR9 receptor in SCA, but it is known to bind to CPG-DNA, which is frequent in bacteria and rare in eukaryotic cells [65], and also has been described to be up-regulated in obese asthmatic patients [30]. 

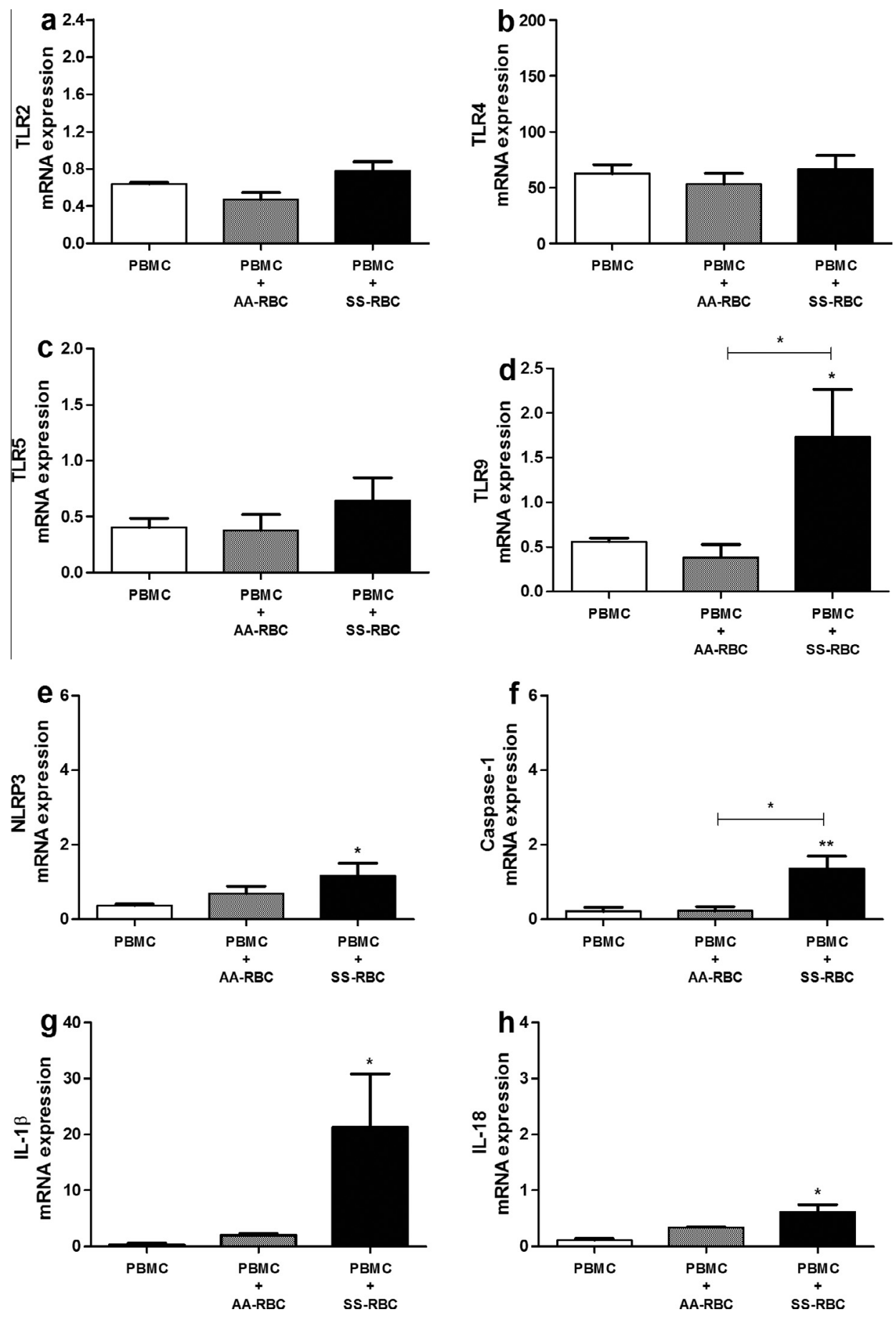

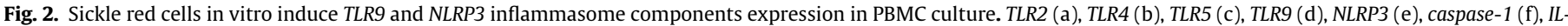

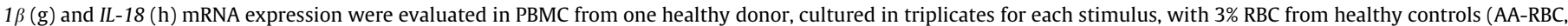

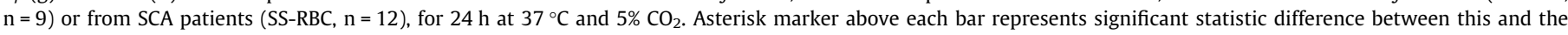

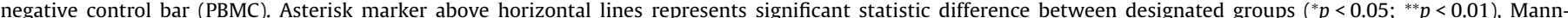

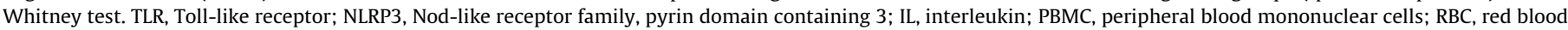
cells; SCA, sickle cell anemia.

Thus, we showed that, in addition to TLR4, the expression of TLR2, TLR5 and TLR9 may contribute to the inflammatory condition described in SCA, and could act as an aggravating factor in patient's condition.

Previous studies show that NLRP3 inflammasome expression is improved in inflammatory diseases $[47,48,66]$. In this study, we showed that NLRP3-inflammasome is expressed in fresh SS-PBMC and it is an important innate immunity platform able to recognize SS-RBC as DAMPs. SCA patients demonstrated higher expression of NLRP3 and IL-1 $\beta$ in fresh PBMC, and SS-RBC induced caspase-1, $I L-1 \beta$ and $I L-18$ expression in PBMC culture. Thus, we showed here that SS-RBC induced IL-1 $\beta$ expression and production, suggesting that its production is induced by specific eDAMP from SS-RBC.

The most common inflammasome is associated with NLRP3, caspase- 1 and ASC. Several danger signals have been well 

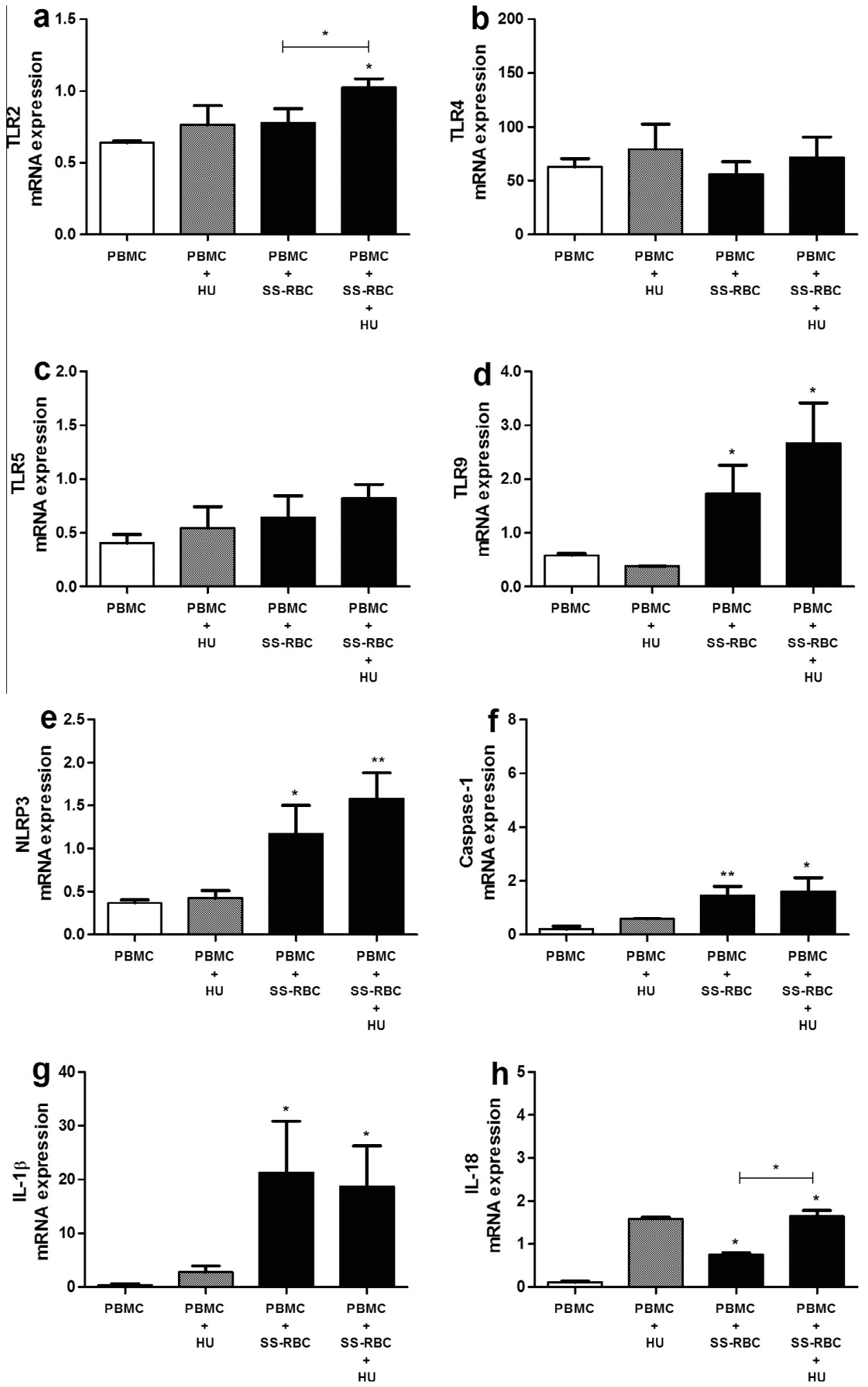

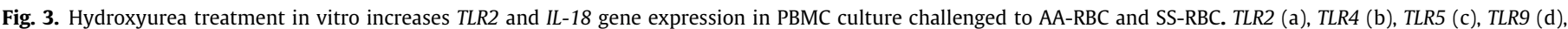

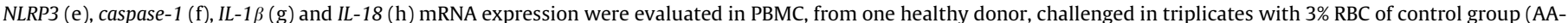

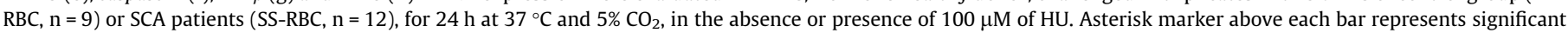

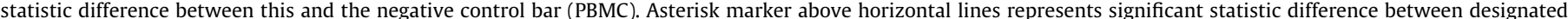

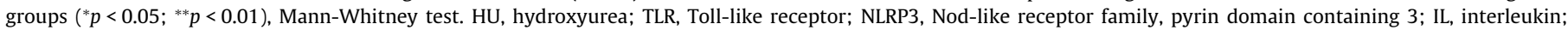
PBMC, peripheral blood mononuclear cells; SCA, sickle cell anemia; RBC, red blood cells.

documented as NLRP3-inflammasome agonists, such as extracellular ATP, glucose, hyaluronan, alum and asbestos [67]. More recently, some authors have demonstrated RBC acting as DAMPs for NLRP3 inflammasome activation, and proposed eDAMPs as a new terminology for these signals of red cells injury [31,68]. Following NLRP3 activation, caspase- 1 becomes active and therefore converts pro-IL-1 $\beta$ and pro-IL-18 in their active forms which are secreted in the extracellular milieu [35]. 

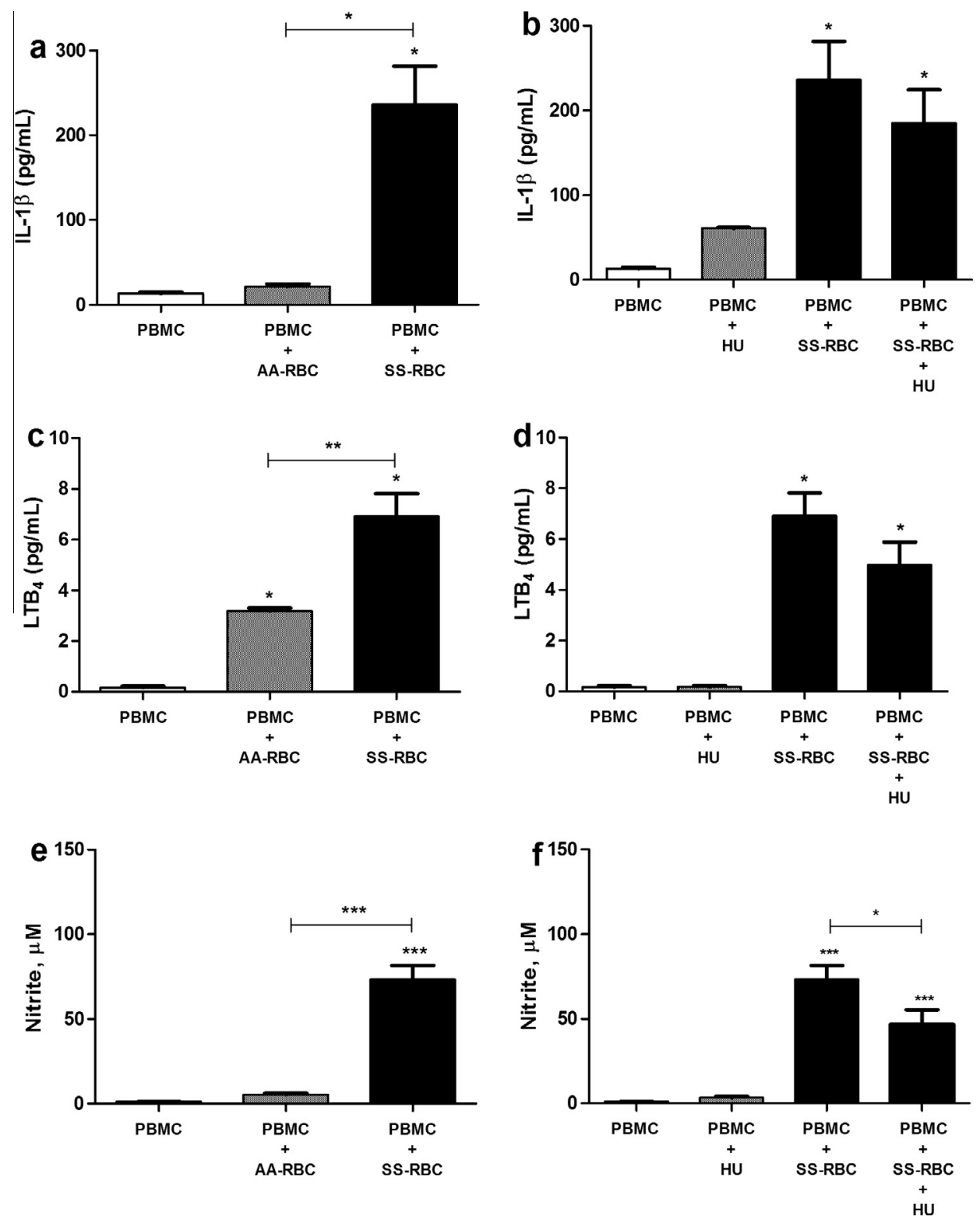

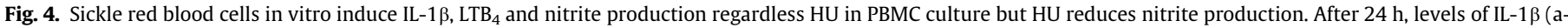

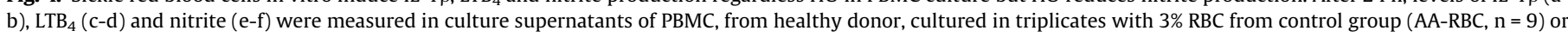

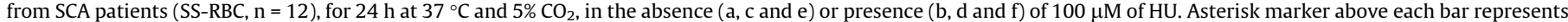

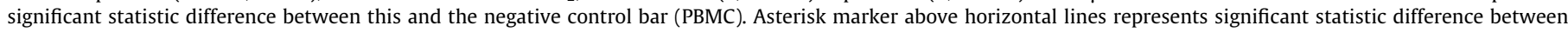

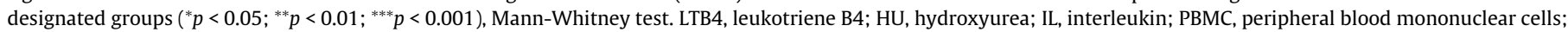
SCA, sickle cell anemia; RBC, red blood cells.

No significant differences were found in caspase-1 and IL-18 expression between fresh AA-PBMC and SS-PBMC; however, NLRP3 and $I L-1 \beta$ showed higher expression in fresh SS-PBMC. It is well documented that many of the same stimuli are able to induce expression of both pro-IL-1 $\beta$ and NLRP3, and that $I L-18$ and caspase-1 are constitutively expressed in many cells $[69,70]$, corroborating our results. Interestingly, our results showed that SS-RBC induced the expression of all NLRP3-inflammasome related molecules evaluated here, suggesting that it can act as eDAMPs for this molecular platform.

Leukotrienes (LT) are important inflammatory mediators, and $\mathrm{LTB}_{4}$ promotes leukocyte migration and adhesion to the vascular endothelium $[71,72]$. Our observation that SS-RBC increased LTB $_{4}$ production in PBMC culture in a significantly more pronounced fashion when compared to AA-RBC is corroborated by the report showing that LT production is augmented in PBMC culture challenged with SS-RBC [72], demonstrating that SS-RBC can amplify the inflammatory response by stimulating leukocyte recruitment.

Another mediator associated with inflammatory condition is NO, which acts inducing vasodilation, inhibiting platelet activation, and thus controlling inflammation. In SCA, concentrations of NO metabolites, such as nitrite, are increased compared with healthy individuals [73]. Several studies show that RBC from SCA patients deplete NO to form its metabolites reducing bioactive NO bioavailability, which may promote vaso-occlusive episodes [73-76]. Our results are in line with these findings, showing that SS-RBC induced higher levels of nitrite when compared to AA-RBC in PBMC cultures.

Pharmacological control of clinical status of SCA patients is achieved mainly by HU therapy, an antineoplastic drug that increases $\mathrm{HbF}$ levels and reduces SS-RBC-endothelial interaction $[49,50]$. In this study, we showed that SS-RBC are not able to induce TLR2 expression in PBMC culture; however, treatment with 
HU significantly increased expression of this receptor. TLR2 is associated with NF- $\kappa$ B activation through the MyD88-dependent pathway, and stimulates the production of proinflammatory cytokines, such as IL-12 and TNF [60]. Moreover, we demonstrated that HU does not decrease the expression of TLR2, TLR4, TLR5 or TLR9, and neither of NLRP3 inflammasome components in PBMC culture, suggesting that this treatment, in addition to increasing TLR2 and IL-18 expression in vitro, is not able to prevent TLR or NLR-mediated inflammation observed in SCA patients.

We demonstrated here that SS-RBC increased $\mathrm{LTB}_{4}$ production in PBMC culture when compared to AA-RBC, and that HU treatment does not interfere in this production. Since $\mathrm{LTB}_{4}$ is associated with SCA immunopathogenesis [15,77], our data suggest that, as observed for TLRs, HU treatment does not reverse the $\mathrm{LTB}_{4}$ dependent inflammatory scenery. However, HU treatment was able to reduce nitrite production, presumably because $\mathrm{HU}$ is a NO donator, improving its bioavailability $[78,79]$. Since NO is associated with vascular homeostasis and the reduction of nitrite levels implicates in higher concentration of bioactive NO [80], our data suggest a beneficial effect of HU treatment on NO levels, corroborating with the study from Gladwin and collaborators [79].

In conclusion, our study suggests that sickle RBC can act as eDAMPs, stimulating TLR and NLR expression and IL-1 $\beta$ cytokine and LTB4 production in PBMC cultures, thus contributing to inflammation. Furthermore, although HU treatment improves several parameters in SCA patients, we highlighted here that HU does not reduce IL-1 $\beta$ and LTB4 production or prevent TLR or NLRP3inflammasome-dependent inflammation, pointing out the need to develop new therapeutic strategies to SCA patients that act by different mechanisms of those observed for HU. Despite requiring further confirmation, our preliminary data suggest that sickle $\mathrm{RBC}$ interfere in the gene expression of inflammatory molecules, and may trigger a complex network in the pathogenesis of SCA.

\section{Conflict of interest disclosure}

The authors declare no competing financial interests.

\section{Authorship}

TNP, RRO and MSG: conceived the study design. TNP: performed all the experiments. DLZ, CCG, RPS and SSS: assisted in all experiments. VMLN: responsible for patients' follow-up. RRO, VVM, JBL and GQC: discussion and accomplishment of some experiments. MOSC: assisted in the collection of samples from patients. LCJA and VMB: discussion of study design, experiments and all results. TNP, RRO, DLZ and MSG: wrote the paper. All authors read and approved the final manuscript.

\section{Acknowledgements}

This work was supported by grants from the Brazilian National Council of Research (CNPq) (311888/2013-5) (M.S.G.); the Foundation of Research and Extension of Bahia (FAPESB) (3626/2013, 1431040053063, and 9073/2007) (M.S.G.); and PPSUS/FAPESB (020/2013 EFP00007295), (M.S.G.); the Instituto Nacional de Ciência e Tecnologia do Sangue (INCTs) (Coordinated by S.T.O.S.), and MCD/CNPq/MS-SCTIE-DECIT (409800/2006-6), (M.S.G.). Sponsors of this study are public or nonprofit organizations that support science in general. They had no role in gathering analyzing, or interpreting the data. We are greatly grateful to SCA patients, all healthy individuals for trust us and for making possible the realization of this work. Finally, we would also like to thank Wendell Vilas Boas, Bruno Cerqueira, Lúcio Barbosa, Kiyoshi Fukutani, Marcia Weber, Junia Raquel Ferreira, Viviane Junqueira Rocha and Cyntia
Cajado for excellent discussions. TNP received a scholarship from CAPES. L.C.J.A., V.M.B. and MSG have productivity scholarship from CNPq.

\section{References}

[1] D.J. Weatherall, A.B. Provan, Red cells I: inherited anaemias, Lancet 355 (2000) 1169-1175.

[2] J.G.t. Taylor, V.G. Nolan, L. Mendelsohn, G.J. Kato, M.T. Gladwin, M.H. Steinberg, Chronic hyper-hemolysis in sickle cell anemia: association of vascular complications and mortality with less frequent vasoocclusive pain, PLoS ONE 3 (2008) e2095.

[3] O.S. Platt, Sickle cell anemia as an inflammatory disease, J. Clin. Invest. 106 (2000) 337-338.

[4] W. Vilas-Boas, B.A. Cerqueira, A.M. Zanette, M.G. Reis, M. Barral-Netto, M.S Goncalves, Arginase levels and their association with Th17-related cytokines, soluble adhesion molecules (sICAM-1 and sVCAM-1) and hemolysis markers among steady-state sickle cell anemia patients, Ann. Hematol. 89 (2010) 877882.

[5] R. Zennadi, A. Chien, K. Xu, M. Batchvarova, M.J. Telen, Sickle red cells induce adhesion of lymphocytes and monocytes to endothelium, Blood 112 (2008) 3474-3483.

[6] T.N. Pitanga, W. Vilas-Boas, B.A. Cerqueira, M.O. Seixas, C.G. Barbosa, E.V. Adorno, et al., Cytokine profiles in sickle cell anemia: pathways to be unreveled, Adv. Biosci. Biotech. 4 (2013) 7.

[7] B.A. Cerqueira, W.V. Boas, A.D. Zanette, M.G. Reis, M.S. Goncalves, Increased concentrations of IL-18 and uric acid in sickle cell anemia: contribution of hemolysis, endothelial activation and the inflammasome, Cytokine 56 (2011) $471-476$.

[8] J.D. Belcher, C.J. Bryant, J. Nguyen, P.R. Bowlin, M.C. Kielbik, J.C. Bischof, et al., Transgenic sickle mice have vascular inflammation, Blood 101 (2003) 39533959.

[9] K.C. Wood, R.P. Hebbel, D.N. Granger, Endothelial cell P-selectin mediates a proinflammatory and prothrombogenic phenotype in cerebral venules of sickle cell transgenic mice, Am. J. Physiol. Heart Circ. Physiol. 286 (2004) H1608H1614.

[10] A.V. Graca-Souza, M.A. Arruda, M.S. de Freitas, C. Barja-Fidalgo, P.L. Oliveira, Neutrophil activation by heme: implications for inflammatory processes, Blood 99 (2002) 4160-4165.

[11] A.P. Monteiro, C.S. Pinheiro, T. Luna-Gomes, L.R. Alves, C.M. Maya-Monteiro, B. $\mathrm{N}$. Porto, et al., Leukotriene B4 mediates neutrophil migration induced by heme, J. Immunol. 186 (2011) 6562-6567.

[12] N.J. Raat, D.M. Tabima, P.A. Specht, J. Tejero, H.C. Champion, D.B. Kim-Shapiro, et al., Direct sGC activation bypasses NO scavenging reactions of intravascular free oxy-hemoglobin and limits vasoconstriction, Antioxid. Redox Signal. 19 (2013) 2232-2243

[13] R.T. Eberhardt, L. McMahon, S.J. Duffy, M.H. Steinberg, S.P. Perrine, J. Loscalzo, et al., Sickle cell anemia is associated with reduced nitric oxide bioactivity in peripheral conduit and resistance vessels, Am. J. Hematol. 74 (2003) 104-111.

[14] B.O. Ibe, J. Kurantsin-Mills, J.U. Raj, L.S. Lessin, Plasma and urinary leukotrienes in sickle cell disease: possible role in the inflammatory process, Eur. J. Clin. Invest. 24 (1994) 57-64.

[15] B.N. Setty, M.J. Stuart, Eicosanoids in sickle cell disease: potential relevance of neutrophil leukotriene B4 to disease pathophysiology, J. Lab. Clin. Med. 139 (2002) 80-89.

[16] M.T. Gladwin, G.J. Kato, Cardiopulmonary complications of sickle cell disease: role of nitric oxide and hemolytic anemia, Hematol. Am. Soc. Hematol. Educ. Program (2005) 51-57.

[17] P. Vicari, S.A. Adegoke, D.R. Mazzotti, R.D. Cancado, M.A. Nogutti, M.S. Figueiredo, Interleukin-1beta and interleukin-6 gene polymorphisms are associated with manifestations of sickle cell anemia, Blood Cells Mol. Dis. 54 (2015) 244-249.

[18] J.D. Belcher, C. Chen, J. Nguyen, L. Milbauer, F. Abdulla, A.I. Alayash, et al., Heme triggers TLR4 signaling leading to endothelial cell activation and vasoocclusion in murine sickle cell disease, Blood 123 (2014) 377-390.

[19] K. Gupta, HMGB1 takes a "Toll" in sickle cell disease, Blood 124 (2014) 38373838.

[20] N. Bahl, R. Du, I. Winarsih, B. Ho, L. Tucker-Kellogg, B. Tidor, et al., Delineation of lipopolysaccharide (LPS)-binding sites on hemoglobin: from in silico predictions to biophysical characterization, J. Biol. Chem. 286 (2011) 3779337803.

[21] H. Xu, N.J. Wandersee, Y. Guo, D.W. Jones, S.L. Holzhauer, M.S. Hanson, et al., Sickle cell disease increases high mobility group box 1: a novel mechanism of inflammation, Blood 124 (2014) 3978-3981.

[22] A.G. Bowie, I.R. Haga, The role of Toll-like receptors in the host response to viruses, Mol. Immunol. 42 (2005) 859-867.

[23] C. Pfirschke, C. Garris, M.J. Pittet, Common TLR5 mutations control cancer progression, Cancer Cell 27 (2015) 1-3.

[24] R.T. Figueiredo, P.L. Fernandez, D.S. Mourao-Sa, B.N. Porto, F.F. Dutra, L.S. Alves, et al., Characterization of heme as activator of Toll-like receptor 4, J. Biol. Chem. 282 (2007) 20221-20229.

[25] N. Husseinzadeh, S.M. Davenport, Role of toll-like receptors in cervical, endometrial and ovarian cancers: a review, Gynecol. Oncol. 135 (2014) 359363. 
[26] Y. Imai, K. Kuba, G.G. Neely, R. Yaghubian-Malhami, T. Perkmann, G. van Loo, et al., Identification of oxidative stress and Toll-like receptor 4 signaling as a key pathway of acute lung injury, Cell 133 (2008) 235-249.

[27] J.S. Lefebvre, T. Levesque, S. Picard, G. Pare, A. Gravel, L. Flamand, et al., Extra domain A of fibronectin primes leukotriene biosynthesis and stimulates neutrophil migration through activation of Toll-like receptor 4, Arthritis Rheum. 63 (2011) 1527-1533.

[28] K. Yang, X.J. Zhang, L.J. Cao, X.H. Liu, Z.H. Liu, X.Q. Wang, et al., Toll-like receptor 4 mediates inflammatory cytokine secretion in smooth muscle cells induced by oxidized low-density lipoprotein, PLoS ONE 9 (2014) e95935.

[29] I. Jialal, U. Rajamani, B. Adams-Huet, H. Kaur, Circulating pathogen-associated molecular pattern - binding proteins and High Mobility Group Box protein 1 in nascent metabolic syndrome: implications for cellular Toll-like receptor activity, Atherosclerosis 236 (2014) 182-187.

[30] N. Sanchez-Zauco, B. Del Rio-Navarro, C. Gallardo-Casas, J. Del Rio-Chivardi, R. Muriel-Vizcaino, C. Rivera-Pazos, et al., High expression of Toll-like receptors 2 and 9 and Th1/Th2 cytokines profile in obese asthmatic children, Allergy Asthma Proc.: Off. J. Regional State Allergy Soc. 35 (2014) 34-41.

[31] M.T. Gladwin, S.F. Ofori-Acquah, Erythroid DAMPs drive inflammation in SCD, Blood 123 (2014) 3689-3690.

[32] F.F. Dutra, L.S. Alves, D. Rodrigues, P.L. Fernandez, R.B. de Oliveira, D.T. Golenbock, et al., Hemolysis-induced lethality involves inflammasome activation by heme, Proc. Natl. Acad. Sci. U.S.A. 111 (2014) E4110-E4118.

[33] E.J. van Beers, Y. Yang, N. Raghavachari, X. Tian, D.T. Allen, J.S. Nichols, et al., Iron, inflammation, and early death in adults with sickle cell disease, Circ. Res. 116 (2015) 298-306.

[34] S.L. Cassel, F.S. Sutterwala, Sterile inflammatory responses mediated by the NLRP3 inflammasome, Eur. J. Immunol. 40 (2010) 607-611.

[35] S. Mariathasan, D.M. Monack, Inflammasome adaptors and sensors: intracellular regulators of infection and inflammation, Nat. Rev. Immunol. 7 (2007) 31-40.

[36] F. Martinon, K. Burns, J. Tschopp, The inflammasome: a molecular platform triggering activation of inflammatory caspases and processing of prolL-beta, Mol. Cell 10 (2002) 417-426.

[37] R. Zhou, A.S. Yazdi, P. Menu, J. Tschopp, A role for mitochondria in NLRP3 inflammasome activation, Nature 469 (2011) 221-225.

[38] F.G. Bauernfeind, G. Horvath, A. Stutz, E.S. Alnemri, K. MacDonald, D. Speert, et al., Cutting edge: NF-kappaB activating pattern recognition and cytokine receptors license NLRP3 inflammasome activation by regulating NLRP3 expression, J. Immunol. 183 (2009) 787-791.

[39] M.G. Ghonime, O.R. Shamaa, S. Das, R.A. Eldomany, T. Fernandes-Alnemri, E.S. Alnemri, et al., Inflammasome priming by lipopolysaccharide is dependent upon ERK signaling and proteasome function, J. Immunol. 192 (2014) 38813888.

[40] F. Bauernfeind, E. Bartok, A. Rieger, L. Franchi, G. Nunez, V. Hornung, Cutting edge: reactive oxygen species inhibitors block priming, but not activation, of the NLRP3 inflammasome, J. Immunol. 187 (2011) 613-617.

[41] L. Agostini, F. Martinon, K. Burns, M.F. McDermott, P.N. Hawkins, J. Tschopp, NALP3 forms an IL-1beta-processing inflammasome with increased activity in Muckle-Wells autoinflammatory disorder, Immunity 20 (2004) 319-325.

[42] M. Guma, J. Kashiwakura, B. Crain, Y. Kawakami, B. Beutler, G.S. Firestein, et al., JNK1 controls mast cell degranulation and IL-1\{beta\} production in inflammatory arthritis, Proc. Natl. Acad. Sci. U.S.A. 107 (2010) 22122-22127.

[43] M. Kitazawa, D. Cheng, M.R. Tsukamoto, M.A. Koike, P.D. Wes, V. Vasilevko, et al., Blocking IL-1 signaling rescues cognition, attenuates tau pathology, and restores neuronal beta-catenin pathway function in an Alzheimer's disease model, J. Immunol. 187 (2011) 6539-6549.

[44] V. Ramirez-Ramirez, M.A. Macias-Islas, G.G. Ortiz, F. Pacheco-Moises, E.D. Torres-Sanchez, T.E. Sorto-Gomez, et al., Efficacy of fish oil on serum of TNF alpha, IL-1 beta, and IL-6 oxidative stress markers in multiple sclerosis treated with interferon beta-1b, Oxidative Med. Cell. Longevity 2013 (2013) 709493.

[45] N. Ketelut-Carneiro, G.K. Silva, F.A. Rocha, C.M. Milanezi, F.F. Cavalcanti-Neto, D.S. Zamboni, et al., IL-18 Triggered by the Nlrp3 Inflammasome Induces Host Innate Resistance in a Pulmonary Model of Fungal Infection, J. Immunol. 194 (2015) 4507-4517.

[46] F. Tas, C. Tilgen Yasasever, S. Karabulut, D. Tastekin, D. Duranyildiz, Clinical significance of serum interleukin-18 (IL-18) levels in patients with gastric cancer, Biomed. Pharmacother. 70 (2015) 19-23.

[47] I. Mitroulis, P. Skendros, K. Ritis, Targeting IL-1beta in disease; the expanding role of NLRP3 inflammasome, Eur. J. Internal Med. 21 (2010) 157-163.

[48] E.H. Kim, M.J. Park, S. Park, E.S. Lee, Increased expression of the NLRP3 inflammasome components in patients with Behcet's disease, J. Inflamm. 12 (2015) 41

[49] O.S. Platt, Hydroxyurea for the treatment of sickle cell anemia, New Engl. J. Med. 358 (2008) 1362-1369.

[50] M.H. Steinberg, W.F. McCarthy, O. Castro, S.K. Ballas, F.D. Armstrong, W. Smith, et al., The risks and benefits of long-term use of hydroxyurea in sickle cell anemia: a 17.5 year follow-up, Am. J. Hematol. 85 (2010) 403-408.

[51] M. de Montalembert, V. Brousse, C. Elie, F. Bernaudin, J. Shi, P. Landais, Longterm hydroxyurea treatment in children with sickle cell disease: tolerance and clinical outcomes, Haematologica 91 (2006) 125-128.

[52] E. Rojas-Mancilla, A. Oyarce, V. Verdugo, Z. Zheng, R. Ramirez-Tagle, The cluster [Re6Se816]3- induces low hemolysis of human erythrocytes in vitro: protective effect of albumin, Int. J. Mol. Sci. 16 (2015) 1728-1735.
[53] A.H. Ding, C.F. Nathan, D.J. Stuehr, Release of reactive nitrogen intermediates and reactive oxygen intermediates from mouse peritoneal macrophages. Comparison of activating cytokines and evidence for independent production, J. Immunol. 141 (1988) 2407-2412.

[54] M.W. Pfaffl, A new mathematical model for relative quantification in real-time RT-PCR, Nucleic Acids Res. 29 (2001) e45.

[55] R.E. Vance, R.R. Isberg, D.A. Portnoy, Patterns of pathogenesis: discrimination of pathogenic and nonpathogenic microbes by the innate immune system, Cell Host Microbe. 6 (2009) 10-21.

[56] R. Chen, S. Fu, X.G. Fan, M.T. Lotze, H.J. Zeh 3rd, D. Tang, et al., Nuclear DAMP complex-mediated RAGE-dependent macrophage cell death, Biochem. Biophys. Res. Commun. 458 (2015) 650-655.

[57] Y.C. Wang, Y. Zhou, H. Fang, S. Lin, P.F. Wang, R.P. Xiong, et al., Toll-like receptor $2 / 4$ heterodimer mediates inflammatory injury in intracerebral hemorrhage, Ann. Neurol. 75 (2014) 876-889.

[58] J. van Bergenhenegouwen, T.S. Plantinga, L.A. Joosten, M.G. Netea, G. Folkerts A.D. Kraneveld, et al., TLR2 \& Co: a critical analysis of the complex interactions between TLR2 and coreceptors, J. Leukoc. Biol. 94 (2013) 885-902.

[59] O. Takeuchi, K. Hoshino, T. Kawai, H. Sanjo, H. Takada, T. Ogawa, et al. Differential roles of TLR2 and TLR4 in recognition of gram-negative and grampositive bacterial cell wall components, Immunity 11 (1999) 443-451.

[60] F.Y. Liew, D. Xu, E.K. Brint, L.A. O’Neill, Negative regulation of toll-like receptormediated immune responses, Nat. Rev. Immunol. 5 (2005) 446-458.

[61] P. Pimentel-Nunes, L. Afonso, P. Lopes, R. Roncon-Albuquerque Jr., N. Goncalves, R. Henrique, et al., Increased expression of toll-like receptors (TLR) 2, 4 and 5 in gastric dysplasia, Pathol. Oncol. Res.: POR 17 (2011) 677683.

[62] R. Wang, J. Ahmed, G. Wang, I. Hassan, Y. Strulovici-Barel, J. Salit, et al., Airway epithelial expression of TLR5 is downregulated in healthy smokers and smokers with chronic obstructive pulmonary disease, J. Immunol. 189 (2012) 2217-2225.

[63] J.H. Kauppila, A.E. Mattila, T.J. Karttunen, T. Salo, Toll-like receptor 5 (TLR5) expression is a novel predictive marker for recurrence and survival in squamous cell carcinoma of the tongue, Br. J. Cancer 108 (2013) 638-643.

[64] J. Sheridan, D.R. Mack, D.K. Amre, D.M. Israel, A. Cherkasov, H. Li, et al., A nonsynonymous coding variant (L616F) in the TLR5 gene is potentially associated with Crohn's disease and influences responses to bacterial flagellin, PLoS ONE 8 (2013) e61326.

[65] S. Bauer, Toll-like receptor 9 processing: the key event in Toll-like receptor 9 activation?, Immunol Lett. 149 (2013) 85-87.

[66] M.A. Martinez-Godinez, M.P. Cruz-Dominguez, L.J. Jara, A. Dominguez-Lopez, R.A. Jarillo-Luna, O. Vera-Lastra, et al., Expression of NLRP3 inflammasome cytokines and vascular mediators in the skin of systemic sclerosis patients, Israel Med. Assoc. J.: IMAJ 17 (2015) 5-10.

[67] K. Schroder, J. Tschopp, The inflammasomes, Cell 140 (2010) 821-832.

[68] K.P. Potoka, M.T. Gladwin, Vasculopathy and pulmonary hypertension in sickle cell disease, Am. J. Physiol. Lung Cell. Mol. Physiol. 308 (2015) L314-L324.

[69] G. Guarda, M. Zenger, A.S. Yazdi, K. Schroder, I. Ferrero, P. Menu, et al. Differential expression of NLRP3 among hematopoietic cells, J. Immunol. 186 (2011) 2529-2534.

[70] C.A. Dinarello, D. Novick, S. Kim, G. Kaplanski, Interleukin-18 and IL-18 binding protein, Front. Immunol. 4 (2013) 289.

[71] B.N. Setty, S. Kulkarni, M.J. Stuart, Role of erythrocyte phosphatidylserine in sickle red cell-endothelial adhesion, Blood 99 (2002) 1564-1571.

[72] M. Opene, J. Kurantsin-Mills, S. Husain, B.O. Ibe, Sickle erythrocytes and platelets augment lung leukotriene synthesis with downregulation of antiinflammatory proteins: relevance in the pathology of the acute chest syndrome, Pulm. Circulat. 4 (2014) 482-495.

[73] D.C. Rees, P. Cervi, D. Grimwade, A. O'Driscoll, M. Hamilton, N.E. Parker, et al. The metabolites of nitric oxide in sickle-cell disease, Br. J. Haematol. 91 (1995) 834-837.

[74] G.J. Kato, M.T. Gladwin, M.H. Steinberg, Deconstructing sickle cell disease: reappraisal of the role of hemolysis in the development of clinical subphenotypes, Blood Rev. 21 (2007) 37-47.

[75] M.T. Gladwin, A.N. Schechter, F.P. Ognibene, W.A. Coles, C.D. Reiter, W.H. Schenke, et al., Divergent nitric oxide bioavailability in men and women with sickle cell disease, Circulation 107 (2003) 271-278.

[76] D.B. Elias, L.B. Rocha, M.B. Cavalcante, A.M. Pedrosa, I.C. Justino, R.P. Goncalves, Correlation of low levels of nitrite and high levels of fetal hemoglobin in patients with sickle cell disease at baseline, Rev. Bras. Hematol. Hemoter. 34 (2012) 265-269.

[77] J. Knight-Perry, M.R. DeBaun, R.C. Strunk, J.J. Field, Leukotriene pathway in sickle cell disease: a potential target for directed therapy, Expert Rev. Hematol. 2 (2009) 57-68.

[78] M.J. Burkitt, A. Raafat, Nitric oxide generation from hydroxyurea: significance and implications for leukemogenesis in the management of myeloproliferative disorders, Blood 107 (2006) 2219-2222.

[79] M.T. Gladwin, J.H. Shelhamer, F.P. Ognibene, M.E. Pease-Fye, J.S. Nichols, B. Link, et al., Nitric oxide donor properties of hydroxyurea in patients with sickle cell disease, Br. J. Haematol. 116 (2002) 436-444.

[80] C.D. Reiter, M.T. Gladwin, An emerging role for nitric oxide in sickle cell disease vascular homeostasis and therapy, Curr. Opin. Hematol. 10 (2003) 99107. 